\title{
Traffic Congestion Impact on Energy Consumption and Workforce Productivity: Empirical Evidence from a Developing Country
}

\author{
Dr. Jonathan Annan \\ School of Business, Kwame Nkrumah \\ University of Science \& Technology, Ghana \\ John Mensah \\ School of Business, \\ Cape Coast Polytechnic, Ghana \\ Dr. Nathaniel Boso \\ Leeds University Business School, \\ Leeds, LS2 9JT, United Kingdom
}

\begin{abstract}
Vehicular traffic congestion is an important public policy issue as it has the potential to impact fuel consumption and workforce productivity levels. As such, scholarly works have focused on explaining key drivers and outcomes of vehicular traffic congestion. Accordingly, this study examines a web of relationships that involves the individual and joint effects of private car usage and mass transportation services on vehicular traffic congestion as well as the impact of vehicular traffic congestion on fuel consumption and workforce productivity. To examine these relationships primary data is obtained from public school teachers in a metropolitan city of Kumasi in Ghana, an emerging Sub-Sahara African economy. The study finds that while private school teachers' private car usage is associated with increases in road traffic congestion, mass transportation usage does not directly impact traffic congestion levels. A more interesting finding is that high levels of private car usage and increases in mass transport usage jointly impact increases in vehicular traffic congestion. In addition, the study finds that whereas private car usage and vehicular traffic congestion are associated with increases in fuel energy consumption, mass transportation services is found to be associated with greater workforce productivity levels. A key public policy implication is that systematic management of vehicular flow is important for reducing traffic congestion and energy consumption in urban centers and for increasing workforce productivity.
\end{abstract}

Keywords: Transportation, Traffic Congestion, Energy Consumption. Workforce Productivity

\section{INTRODUCTION}

Transportation has a crucial role to play in economic development of any nation as it is has been recognized as the means by which communities and sectors of an economy fully participate in a nation's industrialization efforts [3]. For example, World Bank records show that by 2007, nearly $20 \%$ of World Bank lending activities were for transportation infrastructure construction projects, which was larger than lending to health and educational 
sectors combined [46]. Thus, the relevance of transportation in an economy cannot be underestimated [30] as a provision of a high quality transport system is key to national development and the well-being of the society at large [36]. According to [16], an effective transportation system is important in sustaining economic growth in contemporary economies since it provides a linkage between different parts of the country and the global world [22].

In recent times, it has been estimated that more than $80 \%$ of the world's population live in urban communities [20]. As a result, it is argued that quality public transportation system plays an important role in the sustenance, and efficient mobility of high quality urban life [50]. According to [53], public transportation helps reduce traffic congestion, parking congestion, traffic accidents, road and parking infrastructure costs, automobile costs to consumers, excessive fuel energy consumption and air pollution. In addition, the public transport offers the means of mobility for pedestrians such as children, disabled and elderly people.

A major issue that remains under-researched and yet is crucial in explaining urban transportation problems (such as traffic congestion) in less developed nations is the consequences of private car use for transportation. Arguments have been made that as people's disposal income increase there is a greater likelihood of increased private car use [24], but such an increase in private car use has a corresponding knock-on effect on public transport use; hence an increase in traffic congestion. An increase in private car usage may also increase energy demand and reduction in workforce productivity [51,24].

Intrinsically, policy makers have been concerned about the approaches to reduce congestion in Municipal areas to boost energy efficiency and workforce productivity [49]. It is argued that rather than attempt to eliminate traffic congestion in urban centers, policy makers should formulate public policy initiatives that minimize the levels of traffic congestion and its undesirable outcomes [52]. The premises for such a policy direction are that while different regimes have attempted to address the problem in different ways, ranging from road taxes levied on car usage, toll charges for cars entering central business districts (most recently in London), a ban on travelling in high traffic areas during the day, as well as controlling the growth of the vehicle population through possession taxes, none has successfully eliminated the occurrence of traffic congestion and its associated energy consumption and workforce productivity consequences, although a point can be made that in some nations such penalties have helped minimized the incidence and negative outcomes of traffic congestion.

Thus, the central motivation of this research is to contribute to transportation research by advancing knowledge on the underlying causal mechanisms that link private car usage to traffic congestion, the contingency factors that amplifies or mute the relationship, as well as explains energy consumption and workforce productivity consequences of traffic congestion. More specifically, this study proposes a conceptual model to argue that increases in private car usage is a major driver of vehicular traffic congestion, and that this relationship between private usage and traffic congestion is conditioned by levels of mass transport usage. The study then contends that increases in traffic congestion itself is a driver of energy consumption (or demand) and reduction in workforce productivity. By examining this conceptual model, this research seeks to provide valuable contribution to public policy making on road transportation.

First, a major benefit from this study is that it has the potential to enhance current scholarly understanding of the drivers and consequences of a major fuel energy consumption human activity: traffic congestion. In terms of public policy making, findings from the study may help inform public policy makers and traffic congestion experts on key variables, and cause and 
effect relationships to look at when developing remedial measures to minimize traffic congestion in metropolitan areas. Second, an additional benefit from the study is that findings may serve as a source of empirical validation of transportation investment decision making regarding how fuel reserves could be managed to improve national energy security. The sustainability of the national environment is a key issue for the health of a nation [52]. However, empirical verification of the consequence of private car usage, the key drivers of fuel consumption, which is a major indicator of population, is lacking, and yet crucially needed to determine public health implications of fuel energy consumption. Third, the study sought to reveal the vital role of public transportation in reducing energy consumption and pollution and how congestion cost amplifies inefficiencies in the national economy through reduction in workforce productivity. Findings from this study might inform policy experts regarding workforce productivity consequences of traffic congestion. The conceptual model backing these propositions are now explained as follows;

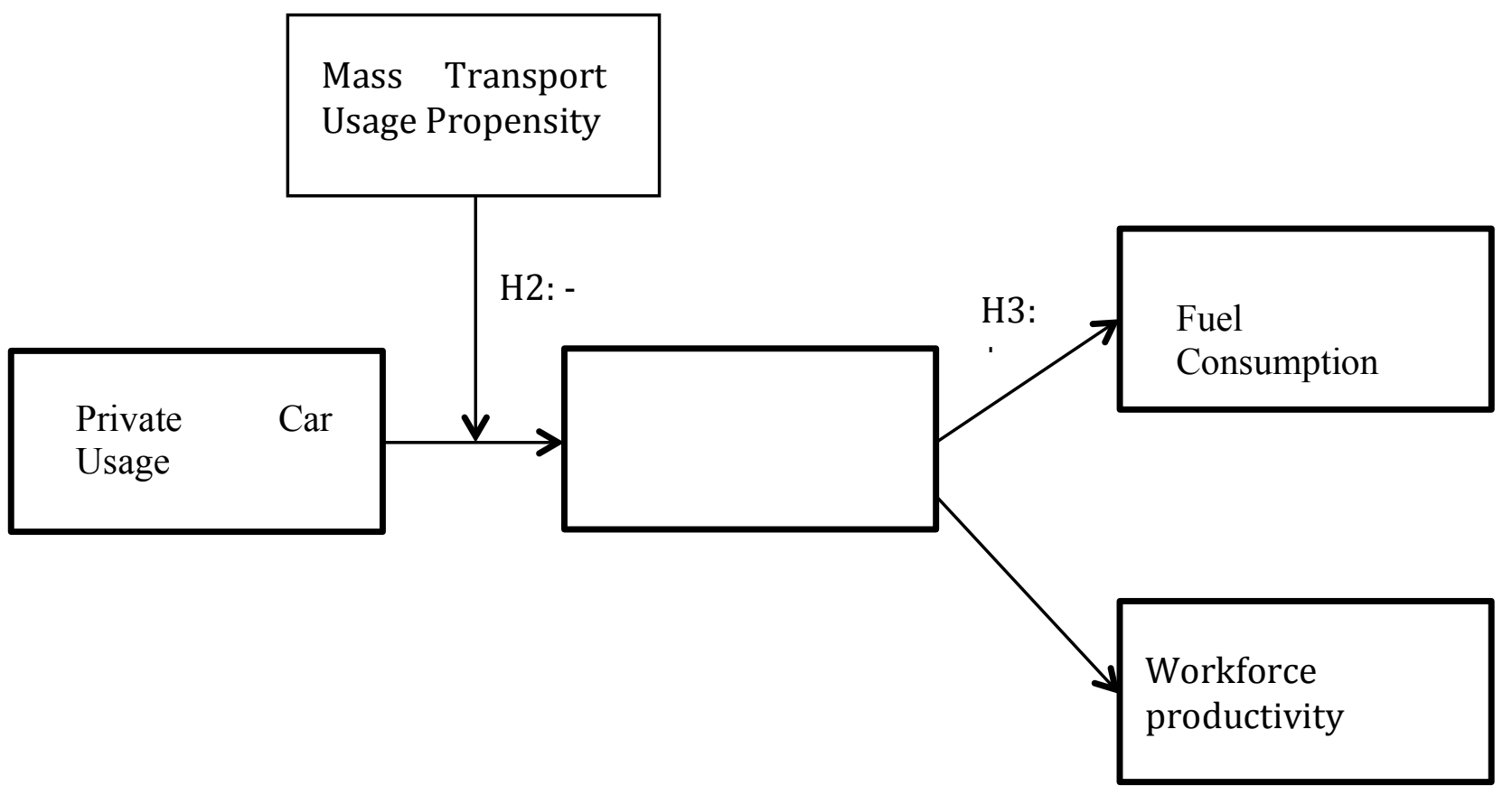

Figure 1: The theoretical background and research hypotheses

\section{Overview of Urban Transportation}

\section{LITERATURE REVIEW}

Urban transportation refers to a system of transportation that provides access and mobility for people, goods and services across urban centers [54]. Effective urban transport systems are essential to economic development and for that matter quality of life in urban areas. Urban transportation opens up opportunities to inhabitants to access essential services. Business activities depend on efficient urban transportation systems to ensure mobility of customers, employees, suppliers and information. According to [54], urban transport services cover a range of important social and economic activities such as leisure trips, business journeys (commuting, shopping) trips to places of education and freight distribution.

\section{Effectiveness of Urban Transportation System}

Effective urban transportation system therefore helps meet demand for accessibility within cities [33]. The effectiveness of an urban transportation system rests very much on the quality and management of transport infrastructure in urban centers including quality of roads, parking lots, vehicles, transportation terminals and networks. In view of the fact that urban transportation infrastructure directly affects urban transportation effectiveness and capacity, 
urban traffic management system becomes an important process for controlling and guiding distribution of traffic on urban roads. In recent times, there has been an on-going movement towards urban transportation system planning, which has an impact on cities and urban settlement development. According to [23], urban transportation system is an essential factor that may facilitate and limit urban economic development depending on the degree of its management for effectiveness and efficiency. Along this line, scholars have identified several factors that may determine the effectiveness and efficiency of transportation systems. Key among these is adequate transport network, traffic management and control systems, efficient and reliable mass transit [16]. [55] also indicated that investment in adequate transport infrastructure improves transport efficiency in terms of increased reliability and productivity. [38] assert that mass transit is prerequisite for ensuring efficient and effective transportation system in urban areas in terms of energy conservation and environmental preservation. Effective traffic management and control system is also noted to enhance transport user mobility and productivity [7].

In particular, it is argued that efficient road transport management helps lower vehicular traffic congestion, and subsequently boost travelers' productivity at work. Productivity is defined as the ratio of volume of output to the volume of input. In other words, it measures the extent to which production input is utilized to produce output in the production process [32]. In advancing this argument further, [16] states that an effective transportation network is therefore key for sustaining economic growth in the contemporary economies. To him, transportation network links people to job, deliver products to markets where there is demand, drives supply chain and logistics and enabling domestic and international trade. He was of the view that improvement in transportation efficiency can influence cost, travel time, reliability, comfort, safety and security. He argued that the direct benefit of an efficient and effective transportation system is reduction in travel time, which translate into cost saving and increase in productivity.

\section{Impact of Transportation on the Economy}

Within the context of developing economies such as Ghana, public bus services have been instrumental for socio-economic mobility [27]. For example, in Ghana the Omnibus Services Authority has contributed to Ghana's economy through provision of transport services nationwide. While vehicular traffic congestion reduction has been one of the key drivers of investment in mass transportation in Ghana, what we currently do not know is empirical evidence to support the notion that greater private car usage accounts for greater variation in traffic congestion in urban centers and that mass transportation helps lower vehicular traffic congestion. In addition, while a lot has been said with respect to the consequences of vehicular traffic congestion on the economy, we lack information on its effects on key economic-related forces: energy consumption and workforce productivity levels. Accordingly, the purpose of the current study is to investigate the extent to which private car usage impact vehicular traffic congestion at differential levels of mass transportation usage, and the degree to which vehicular traffic congestion impact levels of energy consumption and workforce productivity.

\section{Transport and Energy Consumption}

Transportation is essential to our economy and quality of life, and currently accounts for 71\% of the nation's total petroleum use and 33\% of our total carbon emissions. Energy-efficient transportation strategies could reduce both oil consumption and greenhouse gas (GHG) emissions. Petroleum products constitute around 30 percent of total energy demand in Ghana [21]. The transport sector is the main consumer of petroleum products, accounting for over 80 percent of total consumption in 2003. Households accounted for 6.2 percent, industry 6.7 percent and agriculture 4.2 percent [46]. According to [19] increasing urban densities will 
reduces energy consumption by transport and in the same way having more people close to their jobs will also reduce vehicle miles travelled, freeway traffic and tailpipe emissions.

\section{Private Car Usage and Vehicular Traffic Congestion}

\section{HYPOTHESIS DEVELOPMENT}

A high level of private car usage is positively related with high levels of vehicular traffic congestion. A lot of studies indicate that mass or public transportation reduces congestion. According to [37] public transport plays a greater role in reducing congestion. Again [16] notes public transport interventions reduce congestion. [17] Concludes that one of the policies and measures to control urban road transportation externalities like congestion is adopting mass transportation. Finally, [38] demonstrated that, travelling by mass transit per person and per mile, uses significantly less energy and produces substantially less pollution than comparable level by private cars as a result of reduction in congestion.

\section{H1: Private car usage is positively associated with vehicular traffic congestion in urban centers}

\section{Private Car Usage, Mass transportation Usage and Vehicular Traffic Congestion}

The positive effect of Private Car usage on vehicular traffic congestion becomes negative when levels of mass transportation usage increase in magnitude. This argument is in line with [40] suggestion that congestion leads to average speeds that are very low making the car engines consume more fuel than necessary. [38] asserts that public or mass transportation reduces congestion and as such reduces fuel consumption. [11] explains that fuel consumption increases unnecessarily when drivers do not drive at optimal speeds on most frequently used roads. Congestion causes vehicles to more bumper-to-bumper at stop-and-go speeds lower than optimal speeds.

H2: The effect of private cars usage on vehicular traffic congestion in urban centers is weakened when levels of mass transportation usage is high.

\section{Vehicular Traffic Congestion and Fuel Energy consumption}

Energy plays a vital role in the economic activities of any country. Human activities depend on the usage of several forms and sources of energy. In the same vein, transport which is responsible for the mobility of people, goods and services, is also of equal importance to the growth of every economy. Traffic congestion is mostly observed in economically vibrant cities. It is therefore important that congestion is managed in order to ease mobility [28]. [28] explains further that congestion lengthens journey times, disrupts business activities by holding potential business people in traffic and as a result decrease productivity. Again, increasing traffic congestion increases inventory holding cost by manufacturers and wholesalers as a result of travel time unreliability and thereby affecting productivity.

However, the transportation sector worldwide almost entirely depends on fossil energy. While transports may run on several forms of energy, petroleum oil seems to be the most widely used energy to power transportation equipment. A key issue is that as transportation services increase there is a corresponding increase in energy demand. A more interesting issue is that while increases in transportation activities may increase fuel energy demand and consumption, we posit that energy demand and consumption may be greater when increased road transportation cause traffic congestion. Regarding vehicular transportation in particular, argument can be made that when private (as well as public cars) on the road increase vehicular traffic congestion can be expected as a consequence, and congestion, we posit may subsequently cause greater fuel energy consumption by vehicles. While an increased 
petroleum energy demand has become a major issue across the globe in recent times [48], an empirical test linking vehicular traffic congestion to energy consumption, particularly in less developed societies, remain limited.

H3: Increases in vehicular traffic congestion is related to greater energy consumption.

\title{
Vehicular Traffic Congestion and Workforce Productivity
}

Traffic congestion is mostly observed in economically vibrant cities. It is therefore important that congestion is managed in order to ease mobility [28]. [28] explains further that congestion lengthens journey times, disrupts business activities by holding potential business people in traffic and as a result decrease productivity. Again, increasing traffic congestion increases inventory holding cost by manufacturers and wholesalers as a result of travel time unreliability and thereby negatively affecting productivity levels. [40] argues that for those who are caught in congested condition outside normal working hours; it is arguable that the time losses suffered as a result of the congested conditions have impact on the economy. However, one can argue that time outside working hours does not only have economic impact but also increase people's stress level, which subsequently negatively impact productive levels at work. Thus, we hypothesize that:

H4: Vehicular traffic congestion is negatively related to workforce productivity.

\section{Data Collection}

\section{RESEARCH METHODS}

To test the study's proposed hypotheses, we conducted survey and field experiments with commuters that use private vehicles and mass transportation services in a large metropolitan city in Ghana. Specifically, public and private school teachers were included in the study. The study adopted face-to-face interview and questionnaire administration procedures to solicit information from the key informants (i.e. teachers who own private cars). Field experiments and the judgmental sampling technique then used to create a sampling frame of 1000 teachers, from which a sample size of 250 valid responses was obtained.

\section{Measure development}

We followed several procedures to measure the study's key constructs. Specifically, measures of private car usage, traffic congestion, and workplace productivity were newly developed as there were no readily available measures in the empirical literature to capture these constructs. The psychometric procedures suggested by the literature were followed in designing a questionnaire, which was pre-tested with several teachers and academic experts in transportation and supply chain management disciplines [12, 14]. Items measuring workplace productivity were drawn from the literature, as these measures have previously been validated within the context of teacher's competence [25]. In addition to the measures used to estimate the study's hypotheses, we also controlled for several variables in our model, in line with the established literature in the transportation literature (See Table 2).

\begin{abstract}
ANALYSES
Assessments

Following [8], we examined the extent to which there were significant differences in the means of a number of important variables across early and late respondents. We obtained insignificant differences in the means of the teachers' age, income, working hours and weekly expenses on fuel between early and late respondents, indicating that non-response bias is lacking in our data. Subsequently, we performed the Harman one factor test to assess any potential common method bias problem [35]. We specifically estimated a Confirmatory Factor
\end{abstract}


Analysis (CFA) model by forcing all items measuring our constructs to load on a single bias factor. We obtained unsatisfactory results for our sample, indicating that common method bias is not a threat to our dataset.

\section{Reliability and Validity Tests}

For measure development and model testing purposes, a two-stage analytical approach was used whereby the measurement and structural models were tested consecutively, following [5] recommendation. First, an Exploratory Factor Analysis (EFA) was undertaken to determine the factor pattern and structure of the indicators used to measure the constructs. Having obtained a satisfactory factor structure, whereby each observed item loaded expectedly on the hypothesized factor, a Cronbach alpha was calculated for the set of items measuring each obtained factor. Each factor returned a satisfactory alpha value (see Table 1), demonstrating initial evidence of reliability of the measures.

\section{Table 1: Details of Multi-item Measures and Results of Validity Tests}

Construct and Item Details
Private Car Usage ( $1=$ strongly disagree; 5 = strongly agree)
I regularly travel on my private car to and from work
I prefer to commute to and from work on my private car
I find it convenient travelling on my private when it comes to my work
It is important that I travel on my private car for work-related activities
I use my private car to and from work on every working day
Driving my private car to and from work is something that excites me*
Traffic Congestion ( $1=$ not at all; $5=$ to an extreme extent)
I often experience heavy traffic congestion on my way to and from work
There is often heavy traffic congestion on the road leading to my workplace
I spend lots of time on the road travelling to and from work due to traffic
congestion
Driving in a heavy traffic is a normal experience during my working days
I need to leave home very early simply to avoid heavy traffic congestion
I arrive home late after work due to heavy traffic congestion

Mass Transportation $(1=$ not at all; $5=$ to an extreme extent $)$

When travelling to and from work, I am ......

happy to use a public mass transport

open to the idea of using a public mass transport

willing to sit on a public mass transport

prepared to join a public mass transport

$\begin{aligned} & \text { Standardized } \\ & \text { Factor } \\ & \text { Loadings } \$\end{aligned}$
.87 (fixed)
$.84(15.31)$
$.78(13.76)$
$.52(8.12)$
$.78(13.64)$
-

.84 (fixed)
$.87(16.63)$
$.90(17.56)$
$.77(13.57)$
$.82(15.04)$
$.82(14.93)$

Workplace Productivity ( 1 = strongly disagree; 5 = strongly agree $)$

During the past four weeks.....

I have been able to finish hard tasks at work

I have been able to take pleasure in my work tasks

I feel hopeless about finishing certain work tasks*

I have been able to focus on achieving my goals at work

I feel energetic enough to be able to complete all my work tasks
.93

.74

84 (fixed)

$87(16.63)$

$77(13.57)$

$82(14.93)$

.86

.87

.63

.61 (fixed)

$.80(9.36)$

$.91(10.03)$

$.82(9.56)$

.78

.80

.50

.67 (fixed)

$.62(7.48)$

$.81(8.17)$

$.75(8.38)$

.76

.78
Fuel Consumption ( $1=$ not at all; $5=$ to an extreme extent $)$

I use many litres of petrol/diesel every week (Monday to Friday) when school is in session

I spend lots of money on petrol/diesel every week (Monday to Friday) when school is in session

I spend a high percentage of my monthly salary on petrol/diesel every week

(Monday to Friday) when school is in session

\section{Fit Indices}

Chi-square (DF)
P-value .001

$\begin{array}{ll}\text { RMSEA } & \text { NNFI } \\ .046 & .96\end{array}$

CFI

.96
Average

Variance Extracted

.60

291.04 (199)

$\neq=\mathrm{T}$-values are in parentheses

$*=$ deleted items due to poor factor loading
SRMR

.051 
Subsequently, a CFA was performed for each item that passed the EFA and alpha reliability tests. The purpose for the CFA test was to ensure that the reliability and validity of all constructs was robust and with measurement error being accounted for. As can be seen from Table 1, satisfactory factor loadings were obtained for each multi-item construct, demonstrating evidence of convergent validity. In using [9] model fit assessment criteria, overall good fitness indices were obtained for the sample: chi-square $(\chi 2) /$ d.f. $=291.04 / 199=$ 1.46; p-value > .05, which is statistically non-significant; Root Mean Square Error of Approximation (RMSEA) = .046; Non-Normed Fit Index (NNFI) = .96; Comparative Fit Index $(\mathrm{CFI})=.96$; and Standardized Root Mean Residual $(\mathrm{SRMR})=.051$. In addition, the factor loadings for each indicator on its respective construct were statistically significant at $1 \%$ level, and because no evidence of cross-loadings was observed, it is argued that the constructs demonstrate unidimensionality in the sample studied.

Additionally, we find that the composite reliability of each construct was larger than .70, which exceeds [10] .60 recommendations. Similarly, evidence of discriminant validity for each construct was obtained because the lowest Average Variance Extracted was .51, which is larger than the highest shared variance between any pair of constructs. In following [5] recommendation, each possible pair of construct was collapsed into a single factor, and in comparing their fit indices, it was found that the two-factor models provided superior fit to the data relative to the single factor models. Details of these statistics are available in Table 1 and Table 2. Details on the descriptive statistics and inter-construct correlations for the variables that were included in the model are available in Table 2.

\section{Structural Model Estimation}

Having found support for measurement reliability and validity for each construct, we then estimated the structural relationships between variables. We used moderated structural equation modeling (MSEM) to test the moderating effect relationships in the study's theoretical frame work $[13,18]$. Actual estimation of structural models was undertaken using maximum likelihood estimation method, which was implemented in LISREL 8.5. In following [34], model complexity was reduced by creating single indicants for each construct involved in multiplicative interactions (i.e. private car usage and mass transportation usage), while the remaining variables were estimated with full-information, producing a MIMIC model (Multiple Indicator Multiple Cause). For the constructs that were used for multiplicative interactive analysis, the scores were mean-centered, helping to minimize any multicollinearity problem. Subsequently, a series of three nested models were estimated and compared to test the hypotheses. Table 3 reports result of the estimated effects of the explanatory variables on the different dependent variables in the estimated structural model.

Concerning the exact hypotheses tested, hypotheses 1 theorizes that high levels of private car usage are positively related to high levels of vehicular traffic congestion. Findings from this study show that high levels of private car usage are positively related to increases in traffic congestion $(\mathrm{t}=2.22 ; \mathrm{p}<.05)$, in support of $\mathrm{H} 1$. In hypothesis 2 , it is posited that the positive effect of private car usage on vehicular traffic congestion becomes negative when levels of mass transportation usage are high. Findings from the study reveals that when levels of mass transport usage are high, the increase is not significantly associated with reduction in the impact of private car usage on traffic congestion $(t=-1.01 ; p>.05)$, thus, rejecting $\mathrm{H} 2$. In hypothesis 3 , it is conjectured that high levels of vehicular traffic congestion is positively related to high levels of fuel consumption. Evidence from the study indicates that high levels of traffic congestion is positively associated with greater levels of fuel consumption $(t=1.95 ; \mathrm{p}<$ .05), providing support for H3. Additionally, evidence from the study shows that increases in 
traffic congestion is not significantly associated with reduction in workforce productivity contrary to our prediction in hypothesis 4 .

Additional interpretation of the study's findings is appropriate to provide additional insights. We find that at high levels of private car use, traffic congestion becomes higher $(\mathrm{t}=2.21$; $\mathrm{p}<$ $.05)$, and high levels of traffic congestion is associated with increases in fuel congestion ( $t=$ $1.91 ; \mathrm{p}<.05$ ). Furthermore, it was found that high levels of fuel consumption is negatively related to workforce productivity, such that as levels of fuel consumption increases there is a corresponding decreases in workforce productivity, suggesting that high traffic congestion drives decreases in workforce productivity only through increases in fuel consumption, such that the negative impact of traffic congestion on workforce productivity is magnified when it is channeled through increases in fuel consumption. It can, therefore, be inferred that the impact of traffic congestion on workforce productivity is through increases in fuel consumption.

Similarly, it can be argued from the findings that the impact that private car usage has on fuel consumption is through the increase in traffic congestion which is also created by the increase in private car usage. While the propensity to use mass transportation does not affect traffic congestion levels, however, at high levels of mass transportation usage there is a corresponding increase in workforce productivity $(t=1.70 ; \mathrm{p}<.05)$. We discuss the theoretical and policy implications of the findings in the sections that follow next.

Table 2: Descriptive Statistics and Inter-Construct Correlation

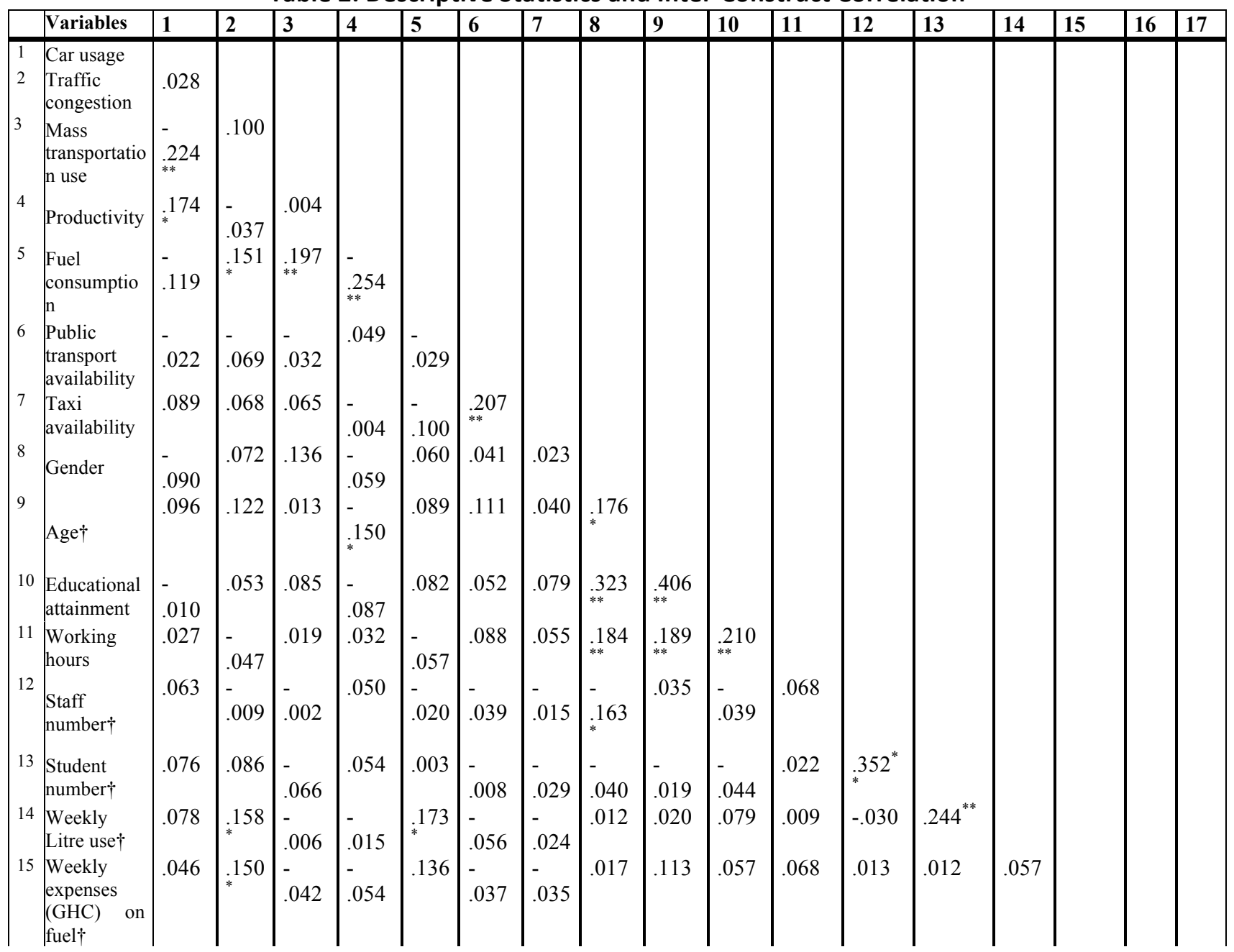




\begin{tabular}{|c|c|c|c|c|c|c|c|c|c|c|c|c|c|c|c|c|c|c|}
\hline $\begin{array}{l}16 \\
17\end{array}$ & $\left|\begin{array}{ll}\% & \text { of } \\
\text { monthly } & \\
\text { income on } \\
\text { fuel } \\
\text { Car size } \dagger\end{array}\right|$ & $\begin{array}{l}- \\
.010 \\
.034\end{array}$ &.- & .089 & $\begin{array}{l}- \\
.016\end{array}$ & $\begin{array}{l}- \\
.066 \\
\end{array}$ & - & .163 & $\begin{array}{l}- \\
.229 \\
.007\end{array}$ & $\begin{array}{l}- \\
.160 \\
.184\end{array}$ & $\begin{array}{l}- \\
.222 \\
.053\end{array}$ & $\begin{array}{l}. \\
.174^{*} \\
.009\end{array}$ & -.072 & .024 & .001 & -.058 & $\begin{array}{l}.06 \\
5 \\
\end{array}$ & - \\
\hline & $\begin{array}{l}\text { Mean } \\
\text { Standard } \\
\text { Deviation }\end{array}$ & $\begin{array}{l}4.30 \\
.88\end{array}$ & $\begin{array}{l}3.36 \\
1.17\end{array}$ & 1.12 & $\begin{array}{l}4.07 \\
.80\end{array}$ & $\begin{array}{l}1.66 \\
.71\end{array}$ & - & - & - & $\begin{array}{l}1.82 \\
.98\end{array}$ & - & $\begin{array}{l}128.3 \\
1 \\
39.59\end{array}$ & $\begin{array}{l}138.1 \\
3 \\
145.6 \\
1 \\
\end{array}$ & $\begin{array}{l}927.54 \\
1071.2 \\
3\end{array}$ & $\begin{array}{l}36.4 \\
9 \\
64.5 \\
0 \\
\end{array}$ & $\begin{array}{l}109.4 \\
3 \\
192.2 \\
9 \\
\end{array}$ & \begin{tabular}{|l|}
6.4 \\
3 \\
2.6 \\
3 \\
\end{tabular} & \begin{tabular}{|l|}
8.6 \\
7 \\
8.4 \\
4 \\
\end{tabular} \\
\hline
\end{tabular}

$\dagger=$ Natural log was taken before correlations were estimated

$\mathrm{N}=202$ private car users

Table 3: Results of Hierarchical Moderated Regression Analyses

\begin{tabular}{|c|c|c|c|c|c|c|c|c|c|}
\hline \multirow{2}{*}{$\begin{array}{l}\text { Independent } \\
\text { variables and } \\
\text { estimated paths }\end{array}$} & \multicolumn{3}{|c|}{$\begin{array}{lll}\text { Dependent } & \text { variable: } & \text { Traffic } \\
\text { Congestion } & & \\
\end{array}$} & \multicolumn{3}{|c|}{$\begin{array}{lll}\text { Dependent } & \text { variable: } & \text { Fuel } \\
\text { Consumption } & & \end{array}$} & \multicolumn{3}{|c|}{$\begin{array}{l}\text { Dependent variable: Workforce } \\
\text { Productivity }\end{array}$} \\
\hline & Model 1 & Model 2 & Model 3 & Model 4 & Model 5 & Model 6 & $\begin{array}{l}\text { Model } \\
7\end{array}$ & Model 8 & Model 9 \\
\hline \multicolumn{10}{|l|}{ Control paths } \\
\hline Staff number & $\begin{array}{l}-.09 \\
(-1.17)\end{array}$ & $\begin{array}{l}-.08 \\
(-1.01)\end{array}$ & $\begin{array}{l}-.08 \\
(-1.01)\end{array}$ & $\begin{array}{l}-.15 \\
(- \\
1.94 * *)\end{array}$ & $\begin{array}{l}-.04 \\
(-1.44 *)\end{array}$ & $\begin{array}{l}-.05 \\
\left(-1.47^{*}\right)\end{array}$ & $\begin{array}{l}.09 \\
(1.09)\end{array}$ & $\begin{array}{l}.06 \\
(.79)\end{array}$ & $.06(.79)$ \\
\hline $\begin{array}{l}\text { Student } \\
\text { population }\end{array}$ & $\begin{array}{l}.13 \\
(1.75 * *)\end{array}$ & $\begin{array}{l}.13 \\
(1.71 * *)\end{array}$ & $\begin{array}{l}.13 \\
(1.70 * *)\end{array}$ & $\begin{array}{l}.01 \\
(.12)\end{array}$ & $\begin{array}{l}-.01 \\
(-.23)\end{array}$ & $\begin{array}{l}-.01 \\
(-.16)\end{array}$ & $\begin{array}{l}.07 \\
(.95)\end{array}$ & $\begin{array}{l}.07 \\
(.93)\end{array}$ & $\begin{array}{l}.07 \\
(.93)\end{array}$ \\
\hline Age & $\begin{array}{l}.13 \\
\left(1.88^{* *}\right)\end{array}$ & $\begin{array}{l}.13 \\
(1.82 * *)\end{array}$ & $\begin{array}{l}.13 \\
\left(1.80^{* *}\right)\end{array}$ & $\begin{array}{l}.10 \\
(1.39 *)\end{array}$ & $\begin{array}{l}.05 \\
(1.59 *)\end{array}$ & $\begin{array}{l}.05 \\
(1.63 *)\end{array}$ & $\begin{array}{l}-.16 \\
(-2.04)\end{array}$ & $\begin{array}{l}-.16 \\
(- \\
2.12 * * *) \\
\end{array}$ & $\begin{array}{l}-.16 \\
(- \\
2.11 * * *)\end{array}$ \\
\hline Total fuel litre & $\begin{array}{l}.12 \\
(1.56) \\
\end{array}$ & $\begin{array}{l}.12 \\
(1.57) \\
\end{array}$ & $\begin{array}{l}.12 \\
(1.56) \\
\end{array}$ & $\begin{array}{l}.08 \\
(1.04)\end{array}$ & $\begin{array}{l}.09 \\
(2.95 * * *)\end{array}$ & $\begin{array}{l}.09 \\
(2.96 * * *)\end{array}$ & $\begin{array}{l}.08 \\
(.97) \\
\end{array}$ & $\begin{array}{l}.07 \\
(.82) \\
\end{array}$ & $\begin{array}{l}.07 \\
9.82) \\
\end{array}$ \\
\hline $\begin{array}{l}\text { Total expenses } \\
\text { on fuel }\end{array}$ & $\begin{array}{l}.20 \\
(2.59 * * *)\end{array}$ & $\begin{array}{l}.19 \\
(2.49 * * *)\end{array}$ & $\begin{array}{l}.20 \\
(2.48 * * *)\end{array}$ & $\begin{array}{l}.06 \\
(.79) \\
\end{array}$ & $\begin{array}{l}-.01 \\
(-.39) \\
\end{array}$ & $\begin{array}{l}-.01 \\
(-.31) \\
\end{array}$ & $\begin{array}{l}-.08 \\
(-.98) \\
\end{array}$ & $\begin{array}{l}-.08 \\
(-.98) \\
\end{array}$ & $\begin{array}{l}-.08 \\
(-98) \\
\end{array}$ \\
\hline $\begin{array}{l}\text { Monthly } \\
\text { Working Hours }\end{array}$ & $\begin{array}{l}-.09 \\
(-1.22)\end{array}$ & $\begin{array}{l}-.08 \\
(-1.06)\end{array}$ & $\begin{array}{l}-.08 \\
(-1.06)\end{array}$ & $\begin{array}{l}-.09 \\
(-.122) \\
\end{array}$ & $\begin{array}{l}.01 \\
(.32)\end{array}$ & $\begin{array}{l}.01 \\
(.29) \\
\end{array}$ & $\begin{array}{l}.05 \\
(.71)\end{array}$ & $\begin{array}{l}.03 \\
(.48)\end{array}$ & $\begin{array}{l}.04 \\
(.48)\end{array}$ \\
\hline $\begin{array}{l}\text { Public transport } \\
\text { availability }\end{array}$ & $\begin{array}{l}-.10 \\
(-1.45\end{array}$ & $\begin{array}{l}-.10 \\
\left(-1.45^{*}\right)\end{array}$ & $\begin{array}{l}-.10 \\
(-1.44 *)\end{array}$ & $\begin{array}{l}-.01 \\
(-.23)\end{array}$ & $\begin{array}{l}.01 \\
(.22)\end{array}$ & $\begin{array}{l}.01 \\
(.17)\end{array}$ & $\begin{array}{l}.07 \\
(.86)\end{array}$ & $\begin{array}{l}.07 \\
(.95)\end{array}$ & $\begin{array}{l}.07 \\
(.95)\end{array}$ \\
\hline Taxi availability & $\begin{array}{l}.09 \\
(1.22)\end{array}$ & $\begin{array}{l}.10 \\
(1.33 *)\end{array}$ & $\begin{array}{l}.10 \\
\left(1.33^{*}\right)\end{array}$ & $\begin{array}{l}-.11 \\
\left(-1.45^{*}\right)\end{array}$ & $\begin{array}{l}-.06 \\
(-1.95 * *)\end{array}$ & $\begin{array}{l}-.06 \\
(-1.90 * *)\end{array}$ & $\begin{array}{l}-.01 \\
(-.08)\end{array}$ & $\begin{array}{l}-.03 \\
(-.45)\end{array}$ & $\begin{array}{l}-.03 \\
(-.45)\end{array}$ \\
\hline Gender & $\begin{array}{l}.10 \\
(1.45) \\
\end{array}$ & $\begin{array}{l}.10 \\
(1.37 *)\end{array}$ & $\begin{array}{l}.10 \\
(1.37 *)\end{array}$ & $\begin{array}{l}.07 \\
(1.02) \\
\end{array}$ & $\begin{array}{l}.05 \\
(1.59 *)\end{array}$ & $\begin{array}{l}.05 \\
(1.63 *) \\
\end{array}$ & $\begin{array}{l}-.04 \\
(-.59) \\
\end{array}$ & $\begin{array}{l}-.03 \\
(-.35) \\
\end{array}$ & $\begin{array}{l}-.03 \\
(-.34) \\
\end{array}$ \\
\hline Education & $\begin{array}{l}.05 \\
(.69) \\
\end{array}$ & $\begin{array}{l}.04 \\
(.56)\end{array}$ & $\begin{array}{l}.04 \\
(.56)\end{array}$ & $\begin{array}{l}.11 \\
\left(1.51^{*}\right)\end{array}$ & $\begin{array}{l}.04 \\
(1.24)\end{array}$ & $\begin{array}{l}.04 \\
(1.26)\end{array}$ & $\begin{array}{l}-.02 \quad(- \\
.24)\end{array}$ & $\begin{array}{l}.00 \\
(.03)\end{array}$ & $\begin{array}{l}.00 \\
(.03)\end{array}$ \\
\hline \multicolumn{10}{|l|}{$\begin{array}{l}\text { Main effects } \\
\text { paths }\end{array}$} \\
\hline $\begin{array}{l}\text { Mass } \\
\text { Usage }\end{array}$ & & $\begin{array}{l}-.03 \\
(-.42)\end{array}$ & $\begin{array}{l}.03 \\
(-.41)\end{array}$ & & $\begin{array}{l}-.03 \\
(-.96)\end{array}$ & $\begin{array}{l}-.03 \\
(-.98)\end{array}$ & & $\begin{array}{l}.16 \\
(2.12 * * *)\end{array}$ & $\begin{array}{l}.16 \\
(2.12 * * *)\end{array}$ \\
\hline $\begin{array}{l}\text { Private } \\
\text { Usage }\end{array}$ & & $\begin{array}{l}.16 \\
(2.21)\end{array}$ & $\begin{array}{l}.16 \\
(2.22 * * *)\end{array}$ & & $\begin{array}{l}.89 \\
(30.50)\end{array}$ & $\begin{array}{l}.89 \\
(33.20 * * *)\end{array}$ & & $\begin{array}{l}-.17 \\
(-1.16)\end{array}$ & $\begin{array}{l}-.14 \\
(-.77)\end{array}$ \\
\hline Traffic Congestion & & & - & & & $\begin{array}{l}.15 \\
(1.95 * *)\end{array}$ & & & $\begin{array}{l}-.01 \\
(-.15)\end{array}$ \\
\hline \multicolumn{10}{|l|}{$\begin{array}{l}\text { Interaction effect } \\
\text { paths }\end{array}$} \\
\hline Fuel Consumption & & & - & & - & - & & & $\begin{array}{l}-.42 \\
(- \\
3.97 * * *)\end{array}$ \\
\hline $\begin{array}{l}\text { Private Car Usage } \\
x \text { Mass Transport } \\
\text { Usage }\end{array}$ & & & 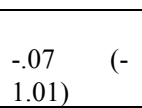 & & - & - & & & - \\
\hline \multicolumn{10}{|l|}{ Fit statistics: } \\
\hline F-value & $3.44 * * *$ & $2.81 * * *$ & $2.60 * * *$ & $2.01 * * *$ & $89.73 * * *$ & $82.48 * * *$ & 1.18 & $1.99 * * *$ & $1.70 * *$ \\
\hline $\mathrm{R}^{2}(\%)$ & .16 & .17 & .16 & .10 & .86 & .89 & .06 & .12 & .15 \\
\hline$\Delta \mathrm{R}^{2}(\%)$ & - & $.01 * *$ & .00 & - & $.76 * * *$ & $.03 * *$ & - & $.06 * * *$ & $.03 * *$ \\
\hline
\end{tabular}

\section{Notes:}

1: Model 1, Model 2 and Model 3 have Congestion as an outcome variable; Model 4, Model 5 and Model 6 have Consumption as an outcome variable; and Model 7, Model 8 and Model 9 have Productivity as an outcome variable. 
2: Model 1, Model 4 and Model 7 = contains control variables; Model 2, Model 5 and Model $8=$ contains control, and main effect variables; and Model 3, Model 6 and Model $9=$ control, main effect, and interactive paths

$3: \mathrm{a}=$ Critical t-value: $* 10 \%$ one-tailed test $=1.28 * ; \%$ one-tailed test $=1.645^{* *}$; and $1 \%$ onetailed test $=1.960^{* * *} ; 4$ : $\mathrm{t}$-values are reported in parenthesis

\section{DISCUSSION AND IMPLICATIONS}

The primary objective of this research was to examine a web of relationships that involves the individual and joint effects of private car usage and mass transportation services on vehicular traffic congestion as well as the impact of vehicular traffic congestion on fuel consumption and workforce productivity. Using primary data from public school teachers in a metropolitan city of Kumasi in Ghana, an emerging Sub-Sahara African economy, the study finds that while private school teachers' private car usage is associated with increases in road traffic congestion, mass transportation usage does not directly impact traffic congestion levels. A more interesting finding is that high levels of private car usage and increases in mass transport usage jointly impact increases in vehicular traffic congestion. In addition, the study finds that whereas private car usage and vehicular traffic congestion are associated with increases in energy consumption, mass transportation services is found to be associated with greater workforce productivity levels. The following sections discuss the theoretical and public policy implications of the findings.

\section{Theoretical implications \\ Policy-making implications}

Congestion reduction should be a central element of a regional economic development strategy in Ghanaian cities. More specifically, policymakers at the urban roads and feeder roads, levels should:

- Pay more attention to the accessibility of other roads within the various suburb, not just downtowns or central business districts where traffic is always at its peak.

- Add capacity in the rims of metropolis, where major suburban job and retail centers are located. Our findings are likely to be productivity-gaining. Not only is access likely to improve more per dollar invested than in the CBD, but future growth is likely to be higher.

- The urban roads approach to transportation planning and investment within the metropolis must have both tactical and strategic dimensions. Tactically, investments must be made in projects and programs that allow the road networks to operate most efficiently and to meet existing travel demand. Strategically, the right infrastructure must be built in the right place at the right time. This is present, Ghana is failing both tactically and strategically, with congestion rising and mobility declining.

- Upgrading freight rail operations is important in reducing road traffic congestions. Lack of adequate road infrastructure (and CBD routes in particular) contributes significantly to rising traffic congestion and lower national economic productivity.

\section{Limitations and directions for future research}

The aim of the study was to investigate how private car usage and mass transportation influence traffic congestion as well as fuel congestion and other levels of externalities. The study used Structural Equation Modelling (SEM) to test the hypotheses of the study developed and concluded that high levels of private car usage lead to increases in traffic congestion. On the other hand, when levels of mass transport usage propensity are high, the increase is not significantly associated with reduction in the impact of private car usage thus rejecting $\mathrm{H} 2$. But 
this can be explained. Studies have shown that increase use of public transport reduces the level of private car usage and as a result, reduction in congestion as found in the literature reviewed. But [24] explained that people sought to live a more comfortable lifestyle and as a result will always prefer to use their private cars as a reliable means of transport than public transport. The public transport systems in developed countries are more comfortable and reliable. Unfortunately in Ghana, our public transport system is dominated by jitneys (trotro) which are mostly uncomfortable and unreliable. Hence people still prefer to use their private cars. Again considering hypothesis 3, the study demonstrated that high levels of traffic congestion are positively associated with greater levels of fuel consumption in support of H3. It can therefore be inferred that the impact of traffic congestion on workforce productivity is through increases in fuel consumption. Similarly, it can be argued from the findings that the impact that private car usage has on fuel consumption is through the increased traffic congestion that the increase in private car usage creates while the propensity to use mass transportation does not affect. Moreover, a number of causes of congestion were observed in the study. These include pedestrian obstruction, inadequate reserved parking lots, dysfunctional traffic control devices, recurrent congestion and picking of passengers anywhere along the roads not necessarily at bus stops. These are mostly due to non-enforcement of transport laws in the cities. The study is limited to emission of $\mathrm{CO} 2$ which is also influenced by the traffic congestion. The model developed in the study could have included emissions as one of the dependent variables of congestion. Thus, the theory could have been high levels of private car usage impacts on traffic congestion and road traffic congestion impacts on emission, fuel consumption and productivity The study did not include research into emissions in Ghana since the Environmental Protection Agency (EPA) has no emissions standards in Ghana [31]. Therefore, research into road traffic emissions and its impact on the environment will be worth studying. This is supported by the fact that pollution as a result of emissions from road traffic congestion from the perspective of developing countries is troublesome as indicated "the spectrum of rapidly growing private vehicle ownership and usage in nations casts a worrying shadow over the projected course of global greenhouse gas emissions" [47]. Finally, the study concludes that, while the propensity to use mass transportation does not affect traffic congestion levels, however, at high levels of mass transportation usage propensity, there is a corresponding increase in workforce productivity.

\section{References}

Agyemang E. (2009).Traffic Congestion: The Bane of a Bus Rapid Transit System in Accra, Ghana?

Alan B., (1995). Urban Mass Transportation Planning. International Edition. Mc Graw Hill Inc. New York, Toronto.

Allport, R.T. and Thompson J.M. (1990), "Study of Mass Rapid Transit in Developing Countries", Report 188, Transport Research Laboratory, Crowthorne.

Amudapuram M. R. and Kalaga R. R. (2012) Measuring Urban Traffic Congestion - A Review, International Journal for Traffic and Transport Engineering, 2(4): 286 - 305, DOI: hp://dx.doi.org/10.7708/ijtte

[5]Anderson J. C, \& Gerbing, D. W. (1988), "Structural equation modelling in practice: a review and recommended twostep approach", Psychological Bulletin, 103: 411- 23

Annan, J. (2014). Urban Road Transportation Systems: Energy Demand, Congestion and Productivity in an Emerging Economy. Unpublished PhD Thesis submitted to Kwame Nkrumah University of science and Technology, Business School.

Arasan, T.V (2012) 'Urban Transportation systems planning'. Unpublished Hand Book presented at Short Term Course organized by Kwame Nkrumah University of Science and Technology and Indian Institute of Technology Madras, Accra.

Armstrong, J.S. \& Overton, T.S. (1977), "Estimating nonresponse bias in mail surveys", Journal of Marketing Research, 14(3), 396-402. 
Annan, J., Mensah, J., \& Boso, N. (2015). Traffic congestion Impact on Energy Consumption and Workforce Productivity: Empirical Evidence from a Developing Country. Archives of Business Research, 3(4), 40-54.

Bagozzi, R. P., \& Yi, Y. (2012), "Specification, evaluation, and interpretation of structural equation models", Journal of the Academy of Marketing Science, 40(1), 8-34.

Bagozzi, R. P. \& Y. Yi (1988), “On the Evaluation of Structural Equation Models”, Journal of the Academy of Marketing Science 16(1): 74-94.

Bonillo, D., (2009), "Fuel demand on UK roads and dieselisation of fuel economy". Energy Policy 37 (10), 3769-3778. Department for Transport (2004), speed: know your limit.[Available at: www.dft.gov.uk] (Accessed 14 May 2013)

Churchill G.A. (1979), "A paradigm for developing better measures of marketing constructs". Journal of Marketing Studies; (16) 12-27

Cortina, J. M., Chen, G., \& Dunlap, W. P. (2001). Testing Interactions Effects in LISREL: Examination and Illustration of Available Procedures. Organizational Research Methods,4(4), 324-360.

DeVellis, R. F. (2003), "Scale Development: Theory and Applications". London, Sage

Dimitriou, H.T., (1991) (Ed.) Transport Planning for Third World Cities. Routelege, Chapman and Hall, Inc.,

Eddington, R., (2006), 'The Eddington Transport Study Main Report: Transport's role in sustaining the UK's Productivity and Competitiveness'.UK Department for Transport,London.[Available at:

www.dft.gov.uk/about/strategy/transportstrategies/eddingtonstudy (Accessed 10th April, 2014)

Gorinda R.T., and Hari, B.Dulal (2010), "Urban Road Transportation Externalities: Cost and choice of Policy Instruments". The Word Bank Research Observer. 26; 162-191

Hair J. F., Block. C.W. Babin B. J., Anderson, R. E and Tathom R. L., (2006), Pearson Education, Inc., upper saddle River, New Jersey

Hickman, R. and Banister, D., (2007). Transport And Reduced Energy Consumption: What Role Can Urban Planning Play? Working paper No 1026, Transport Studies Unit Oxford University Centre for the Environment, http://www.tsu.ox.ac.uk/

Hoornweg, D., Sugar, L., \& Gomez, C. L. T. (2011), “Cities and greenhouse gas emissions: moving forward”. Environment and Urbanization, 23(1), 207-227.

ISSER (2004). - Socio- Economic Impact of Petroleum Deregulation Policy. Accra,University of Ghana (December).

Kulash, D. J. (1999), “Transportation and Society'. [Available at: www.safty.fhwa.dot.gov/pedbike/docs/tph_1.pdf] (Accessed 14th October,2011).

Jian-zhi G, Yao Z., He-ling M., Yuan-Xia S., (2008), “Theoretical analysis on coordinated development of urban transport system", Kybernetes, 37(9), 1308-1314

Jou, R. C., Huang, W. H., Wu, Y. C., \& Chao, M. C. (2012) "The asymmetric income effect on household vehicle ownership in Taiwan: A threshold co-integration approach". Transportation Research Part A: Policy and Practice, 46(4), 696-706.

Lemmens, R. J. M., Timmermans, A. A. A., Janssen-Potten, Y. J. M., Pulles, S. A. N. T. D., Geers, R. P. J., Bakx, W. G. M., ... Seelen, H. A. M. \$2014\$. Accelerometry Measuring the Outcome of Robot-Supported Upper Limb Training in Chronic Stroke: A Randomized Controlled Trial. PLoS ONE, 9\$5\$, e96414. doi:10.1371/journal.pone.0096414

Leo H. (2010), "Welcome to the world's worst traffic jam". The Guardian. [Available at:

http://www.theguardian.com/technology/2010/aug/23/worlds-worst-traffic-jam] (Accessed on 15th April, 2012)

Metro Mass Transit Ltd, Report (2003) [Available at www.mot.gov.gh/page.php?subcat=10] (Accessed 24th November, 2012).

May, A and Marshen, G (2011), 'Urban transport and mobility: Transport and innovation unleashing the potential', International Transport Forum. [Available at: www.internationaltransportforum.org/pub/pdf/10FP05.pdf] (Accessed 5th January, 2012)

Mikosza, O., (2006),,Metropolitan Individual System of Public Transportation(Online; http://www.mist-er.com/mister_com/Opinia Starowicz_1_UK.pdf) 
Morash, Edward A and Steven R Clinton (1997), "The Role of Transportation Capabilities in International Supply Chain Management," Transportation Journal, 36 (3), 5-17.

Mustapha S. (2014), "Life in the Cloud of Exhausts", Daily Graphic publication, 25th March, 2014, [Available at www.graphic.com.gh] (Accessed on 1st May, 2014).

OECD (2006), “Managing Urban Traffic Congestion'. Transport Research Centre, European Conference of Ministers of Transport. Available at: www.internationaltransportforum.org/Pub/pdf/07/Congestion.pdf (Accessed 24th November, 2011).

Okoko, E. (2006), “Quantitative techniques in urban analysis”. Ibadan: Kraft Books Limited

Ping Jr, R. A. (1995), “A parsimonious estimating technique for interaction and quadratic latent variables" Journal of Marketing Research, 336-347.

Podsakoff, P. M., MacKenzie, S. B., Lee, Jeong-Yeon, \& Podsakoff, N. P. (2003), “Common Method Biases in Behavioral Research: A Critical Review of the Literature and Recommended Remedies". Journal of Applied Psychology, 88(5), 879-903.

Rietveld, P. (1989). Infrastructure and regional development. The Ann of Regional Science 23, 255-274.

Santos G., Behrendt H., Maconi L., Shirvani T., and Teytelboym A., (2010), "Externalities and economic policies in road transport". Research in Transportation Economics 28, 2-45

Shapiro R. J., Hassett, A. K., and Anold, S., F., (2002) 'Conserving Energy and Preserving the Environment: the Role of Public Transportation'. American Public Transportation Association. Retrieved from:

www.opta.com/resources/reportstandpublications/.../better-health.pdf. (Accessed 20th October, 2014).

Smerk G M, (1991). The Federal Role in Urban Mass Transportation. Bloomington: Indiana University Press.

Stopher, P. R., (2004), "Reducing road congestion: a reality check". Transport Policy, 11, 117-131this issue, doi: 10.1016/j.tranpol.2003.09.002, [Retrieved from www.researchgate.net/publication/.../79e415107e89c026dc.pd] (Accessed on 1st May, 2014).

The International Bank for Reconstruction and Development / The World Bank (2006). Poverty and Social Impact Analysis of Reforms. Washington DC, The World Bank

Walsh, M. (1990) Global Trends in Motor Vehicle use and Emissions. In Annual Review of Energy, Volume 15, pp. 217243

Weisbrod G., Vary D., \& Treyz G., (2003). "Measuring the Economic Costs of Urban Traffic Congestion to Business". Transportation Research Board. Chicago. <http://www.edrgroup.com/pdf> (Viewed on 1 Jan. 2014)

Weisbrod, Glen, Donald Vary, and George Treyz. (2001). Economic Implications of Congestion, National Cooperative Highway Research Program Report 463, Transportation Research Board, Washington, DC.

(Online:http://onlinepubs.trb.org/Onlinepubs/nchrp/nchrp_rpt_463-a.pdf)

Wells D, (1975). Comprehensive Transport Planning. High WY Combe: Charles Griffin and Company.

World Bank (2007), “A Decade of Action in Transport” [http://www.worldbank.org/ieg] (Accessed on 1st May, 2014).

Wright, L., and Fulton, L., (2005), “Climate change mitigation and transport in developing nations” Transport Reviews, 25 (6), 691-717

Zheng $\mathrm{CH}$, Oh CE, Park YI, Cha SW, 2012. Fuel economy evaluation of fuel cell hybrid vehicle based on equivalent fuel consumption. Journal of Hydrogen Energy, (37): 1790-1796.

Bonsall P. (2006), "How Policymakers are using road charging to tackle congestion”, Economist Intelligence Unit. [Available at graphics.eiu.com/files/ad_pdf/eiu_traffic] (Accessed 14 May 2013)

McCann, P., \& Acs, Z. J. (2011), “Globalization: countries, cities and multinationals”, Journal of Regional Studies, 45(1), 17-32.

Halko J. T. (2012), “Designing Public Transportation for Private Car Users”. [Available at http://www..taik fi/unni.new/ getoptikafile.php] (Accessed on 5th January, 2014) 
Annan, J., Mensah, J., \& Boso, N. (2015). Traffic congestion Impact on Energy Consumption and Workforce Productivity: Empirical Evidence from a Developing Country. Archives of Business Research, 3(4), 40-54.

Levy, J. I., Buonocore, J. J., \& Von Stackelberg, K. (2010), "Evaluation of the public health impacts of traffic congestion: a health risk assessment", Environmental Health, 9(65), 1-12

Litman T., (2007), “Evaluating transportation Equity”, Victoria Transport policy institute, [Available at: www.vtpi.org/equity.pdf] (Accessed 20 June 2012).

Rodrigue, J.P. et al. (2009). 'The Geography of Transportation System'. New York: Routledge. Available at: www.en.wikibooks.org/wiki/Gravity of migration (Accessed 24th November, 2011).

Nadiri M. I., (1998), "Contribution to Highway Capital to Output and Productivity Growth in the US Economy and Industries", [Available at www.fhwa.dot.gov/reports/growth.pdf] (Accessed on 1st May, 2014). 